\title{
SENTENCE APPEALS TO THE ALBERTA COURT OF APPEAL, 1985-1992 A STATISTICAL ANALYSIS OF THE LAYCRAFT COURT
}

\section{PETER McCORMICK*}

The author discusses areas of interest revealed by a statistical analysis of sentence appeals in the Alberta Court of Appeal during the Laycraft period. First he notes the uniqueness of the Alberta Court of Appeal among other Canadian appellate courts, Alberta having a larger amount of sentence appeals than any other jurisdiction. He then goes on to analyze appeals by type of offence, panel composition, the origin of the appeal, and other factors, in each revealing some surprising relationships. In particular, several myths about judicial sentencing are shown to lack statistical support.
L'auteur examine les champs d'intérêt révélés par une analyse statistique des appels de condamnation interjetés auprès de la cour d'appel de l'Alberta durant la période Laycraft. Il note d'abord le caractère unique de celte cour par rappon aux autres cours d'appel du Canada, l'Alberta comptant en effet le plus grand nombre d'appels. II procède ensuite à l'analyse des appels d'après les catégories d'infraction, la composition du tribunal, l'origine des appels et d'autres facteurs, et révèle d'étonnants rapports dans chaque cas. Il démontre notamment que plusieurs mythes relatifs à la détermination de la peine n'ont aucun fondement statistique.

\section{TABLE OF CONTENTS}

I. INTRODUCTION . . . . . . . . . . . . . . . . 624

II. THE ALBERTA COURT OF APPEAL IN

COMPARATIVE CONTEXT $\ldots \ldots \ldots \ldots \ldots \ldots \ldots 626$

III. APPEALS FROM WHERE? SOURCES OF

APPELLATE CASELOAD . . . . . . . . . . . . . . 629

IV. APPEALS OF WHAT? OFFENCE TYPES

AND OUTCOMES .................... 632

V. APPEALS FROM WHOM? THE ALBERTA

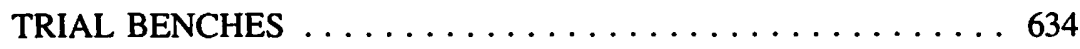

VI. APPEALS BY WHOM? CROWN APPEALS AND

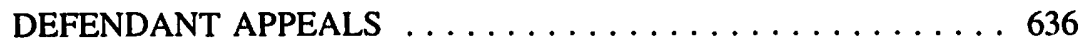

VII. APPEALS TO WHOM? PANEL COMPOSITION

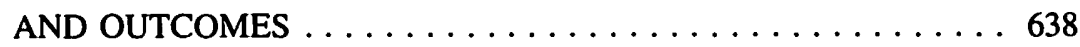

VIII. APPEALS FOR WHAT? DO APPEAL JUDGES TINKER? . . . . 640

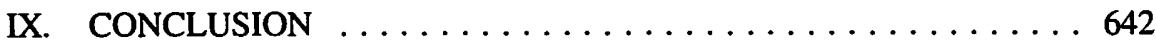

\section{INTRODUCTION}

Caught between the expanding caseload of the trial courts beneath them and the Charter-constricted and increasingly discretionary caseload of the Supreme Court above them, the provincial courts of appeal play a role of growing significance within the Canadian judicial process, although one could argue that what is recent is the awareness of significance, rather than the significance itself. This being the case, it is increasingly

I wish to acknowledge the Alberta Law Foundation, which funded the data collection for this project, and the work of the three student research assistants who helped me in collecting and coding the data: Alex Kotkas, now at the University of Alberta; Scott McCormick, now at the University of Western Ontario; and Tim Moro, at the University of Calgary. 
anomalous that there should be so little hard information about those courts and their operations -- the basic patterns of caseload, patterns and correlations of outcome, evolving trends of caseflow, and so on. This article is an attempt to make up some of this deficiency by examining the statistical record of sentence appeals in the Alberta Court of Appeal between January 1, 1985 and June 30, 1992.' This period corresponds very closely to the Chief Justiceship of Mr. Justice J.H. Laycraft, ${ }^{2}$ and will be treated as a single block rather than trying to assess changes over time within the general interval.

The above paragraph raises three rather obvious questions. First, why a statistical examination? The normal focus for the analysis of judicial decisions, especially appellate decisions, is quite properly the rigorous analysis of the logical argument provided by the Court to explain the outcome and it is these reasoned arguments, rather than specific or aggregate outcomes, that provide the precedent so central to the logic of the common law system. But the individual bricks fit together to form a wall; comments about the specific components at some point turn into (or presuppose) generalizations about the composite whole to which they contribute. At its crudest, without knowledge of what the "normal" or typical outcome looks like, it is impossible to identify the unusual or exceptional case, let alone to assess just how unusual or exceptional it might be. At a less dramatic level, without some understanding, statistical or intuitive, of general patterns of probable outcomes, it is difficult for counsel to advise clients on whether or not to appeal.

Second, why sentence appeals? Clearly, for sentence appeals more than for any other general type, the balance between the legally significant and the idiosyncratic is tilted more heavily toward the latter. With the exception of the occasional "bench-mark" judgment intended to provide clear direction to trial court sentencing decisions, the typical sentence appeal is resolved either as an oral decision from the bench, or in a brief and rather uninformative one or two-paragraph judgment. However, the sheer volume of sentence appeals (at least in some provinces) gives the aggregate a significance that any single case may lack. If one compares the Alberta judicial system to a department store (with the appeal court as one major department within it), and thinks of appellants and respondents as customers seeking particular judicial decisions as the product, then it is clearly the case that the most popular item in the inventory is sentence appeals, however unglamorous they might be and however limited the implications of any single transaction.

Further, the high discretion/low information combination arguably makes sentence appeals the most amenable to statistical coding and analysis. This is precisely because they seldom raise major points of law, seldom generate lengthy and rigorous written decisions with wide precedential implications, and can without distortion or ambiguity or nuance be reduced to questions of "yes/no" and "how much." Nor does it impugn judicial professionalism to look for patterned differences in the exercise of discretion.

These dates are more opportunistic than logical - the Registrar's Office in Edmonton does not retain as archival material the summary lists on which this study is based, and information before January 1,1985 is unavailable.

2 Justice Laycraft was appointed Chief Justice of the province on February 20, 1985 and Justice Fraser was appointed to succeed him on March 12, 1992. 
Third, why the Alberta Court of Appeal? For Alberta practitioners, the answer is, of course, self-evident. In broader terms, however, the Alberta Court of Appeal suggests valuable and possibly generalizable lessons because the sheer volume of its decisions reduces the likelihood that unusual episodes distort the pattern of results, and therefore permits a clarity of conclusion that would be obscured by the much smaller sentence appeal caseload of most other provincial appeal courts.

\section{THE ALBERTA COURT OF APPEAL IN A COMPARATIVE CONTEXT}

The Alberta Court of Appeal is one of Canada's ten provincial superior appeal courts, ${ }^{3}$ nine of which operate within the British common law tradition and all of which oversee the application of a uniform national criminal code. However, this does not imply any common pattern to the size or the component of the caseload of the various appeal courts, nor can the differences be accounted for by the need to accommodate differing provincial population size and/or differing sizes of the provincial courts of appeal. Table 1 demonstrates the diversity that exists in this regard, especially striking for the criminal appeals whose grounding in a national criminal code suggests the greatest potential for some degree of uniformity. Instead, there is no clear pattern for the number of criminal appeals, for the ratio of criminal to civil appeals, or for the ratio of criminal appeals to population. For whatever reason, it is clearly the case that the judicial resources of the various provinces are used by varying actors in different proportion and to different extents.

Table 1: Criminal and Civil Annual Appellate Caseload Canadian Provincial Courts of Appeal ${ }^{4}$

\begin{tabular}{||l|c|c|c||}
\hline Province & Civil Appeals & Criminal Appeals & $\begin{array}{c}\text { Percentage } \\
\text { Criminal }\end{array}$ \\
\hline \hline Alberta & 275 & 746 & $73.1 \%$ \\
\hline Newfoundland & 35 & 65 & $65.0 \%$ \\
\hline Ontario $^{5}$ & 492 & 837 & $63.0 \%$ \\
\hline Saskatchewan & 194 & 304 & $61.0 \%$ \\
\hline
\end{tabular}

3

Although only recently has been the case, Newfoundland acquiring its separate appellate court in 1974 and Prince Edward Island in 1987. See P.H. Russell, The Judiciary in Canada: The Third Branch of Government (Toronto: McGraw-Hill/Ryerson, 1987) Chapter 12.

$1 \quad$ All data for calendar 1989; from P. McCormick (with W.D. Griffiths) "Canadian Provincial Courts of Appeal: A Comparison of Procedures 1992" (Paper presented at 1992 Canadian Appeal Court Seminar in Victoria B.C., May 1992): revised to include figures from British Columbia Court of Appeal Annual Report 1990.

3. Omits inmate appeals, a category which in practice includes a considerable overlap with the criminal appeals category. 


\begin{tabular}{||l|c|c|c||}
\hline \hline Province & Civil Appeals & Criminal Appeals & $\begin{array}{c}\text { Percentage } \\
\text { Criminal }\end{array}$ \\
\hline Manitoba & 184 & 243 & $56.9 \%$ \\
\hline Nova Scotia & 165 & 195 & $54.2 \%$ \\
\hline Prince Edward Island & 34 & 31 & $47.7 \%$ \\
\hline British Columbia & 405 & 286 & $41.3 \%$ \\
\hline New Brunswick & 106 & 58 & $35.4 \%$ \\
\hline Quebec & 830 & 321 & $27.9 \%$ \\
\hline TOTAL: & 2720 & 3086 & $53.2 \%$ \\
\hline
\end{tabular}

The figures in Table 1 are only a crude beginning. It is of course important to distinguish between conviction appeals and sentence appeals. The latter, usually less complex and demanding, make up a significant proportion of the criminal caseload and swell their numbers misleadingly relative to civil caseload. It would also be a mistake to suggest that the conviction/sentence/civil ratio in caseload in any sense parallels the normal weekly judicial workload. Sentence appeals are typically so straightforward that they can be "batch-processed" in large numbers; conviction appeals vary but are generally more routine and repetitive than civil appeals. ${ }^{6}$ However, the "civil" rubric is itself a residual category including an enormous diversity of cases, many of which call for significantly more reading and preparation. ${ }^{7}$ Moreover, the ratio of sentence appeals to conviction appeals within the criminal appeal category is itself far from constant. For example, in Ontario the ratio is almost five to one ${ }^{8}$ while in Manitoba in recent years the numbers are almost even. ${ }^{9}$

Alberta falls between these two extremes. During the Laycraft Court, sentence appeals have been almost exactly twice as frequent as conviction appeals, and make up almost one-half of the appellate caseload. This suggests a rather surprising conclusion: although Alberta is the fourth largest province, its court of appeal may well handle more sentences appeals (both as absolute number and as proportion of total caseload) than any other province except Ontario. Although hard numbers of this sort are not available for a series of years for all the provincial courts of appeal, Alberta figures suggest a gradual decline, overall and for all components of caseload, from a total just over 1350 cases in 1985-86

6

See J.T Wold \& G.A. Caldeira "Perceptions of 'Routine' Decisionmaking in Five California Courts of Appeal" (1980) 13 Polity 334.

7 It has also been suggested to me by appeal judges from several provinces that the complexity of the average civil case, and hence the preparation and discussion time that is called for, has been steadily increasing.

8 Based on figures and comments in C. Baar, I. Greene, M. Thomas and P. McCormick, "The Ontario Court of Appeal and Speedy Justice" (1992) 30 Osgoode Hall LJ. 261.

9 See P. McCormick, "Caseload and Output of the Manitoba Court of Appeal 1990" (1992) 21 Man. L.J. 24 [hereinafter "Caseload and Output"]. 
to about 1000 cases per year over the last three years. This is still easily the highest rate, per capita or per appeal judge, of any province.

To observe such a dramatic difference between the caseload of Alberta and that of other provinces raises the obvious question: why so many sentence appeals in Alberta? A definitive answer is of course impossible, but several factors seem clearly relevant. First, even where the appeal is against both conviction and sentence, the Alberta Court of Appeal does not usually deal with both aspects of the question at the same time. Instead, they will deal with the conviction appeal first, and subsequently and separately with the sentence appeal. ${ }^{10}$ This results in a certain amount of "double-counting," and in a certain number of separate sentence appeal decisions that would in other provinces be folded into the statistics for conviction appeals."

Second, unlike other provinces, the Alberta Court of Appeal does not normally use the "leave to appeal" process as a screening mechanism preliminary to actual panel consideration of the details of a case; rather, they sit as a panel to hear at least a first round of argument before rendering a decision that will either deny leave or simultaneously grant leave and render a substantive conclusion. ${ }^{12}$ In fact, several cases were recorded as "leave denied and appeal dismissed," a logical gaffe which is completely understandable given the way that Alberta practice blurs the distinction between the two.

Third, the Alberta Court of Appeal makes extensive use of superior trial court judges sitting as ad hoc members of the Court of Appeal, especially (but not only) on sentence appeals. Whatever its other implications, such a practice is clearly efficient to judges in terms of caseload capacity and caseflow. By regularly using trial judges to supplement their numbers, any given number of appeal judges can clear a larger number of sentence appeals in a shorter period of time. But the caseload itself is not a completely independent variable; arguably, this higher degree of efficiency in itself tends to call forth a larger number of appeals that would be discouraged by a more ponderous process. ${ }^{13}$

This data collection compounds the double-counting problem by including the sentence component of 214 cases that did decide both conviction and sentence appeal simultaneously.

The impact of this factor should not be overstated. Even if one assumed that every conviction appeal was also a sentence appeal (which is clearly not the case) Alberta's criminal and sentence caseload would still be second only to Ontario's. of Appeal Annual Report 1990, supra note 4 for example, suggests that in recent years very few sentence appeals have been screened out in this manner.

13 "The basic price mechanism for access to courts has proven to be queuing (which implies waiting time).... Expansion of public capacity lowers costs and brings on more cases; contraction tends to deflate the number of cases." S. Krislov, "Theoretical Perspectives on Case Load Studies: A Critique and a Beginning" in K.O. Boyum \& L. Mather, eds., Empirical Theories About Courts (New York \& London: Longman, 1983) 168. 
Fourth and finally, as will be elaborated at several points in this article, the Alberta Court of Appeal implicitly encourages sentence appeals by the simple and obvious fact of allowing so many of them; a high success rate is clearly a signal to potential appellants that the game may very well be worth the candle. By way of contrast, anecdotal information from other Courts of Appeal suggest that they are much more reluctant to grant leave, and much more reluctant to second-guess a trial judge in the absence of grievous and glaring error. ${ }^{14}$ This double message should logically serve to discourage sentence appeals save in unusual circumstances.

\section{APPEALS FROM WHERE? SOURCES OF APPELLATE CASELOAD}

By definition, an appeal court hears appeals from the decisions of trial courts. In a strict hierarchy, this would mean appeals from the provincial superior trial court (in Alberta, the Court of Queen's Bench); in the modified hierarchy of the Canadian criminal system, this can, and often does, involve appeals from the Provincial Court as well. Table 2 provides the seven-year breakdown of the appellate caseload in these terms, with the success rate of appeal from each source.

The first general observation about the figures in Table 2 is the high volume of appeals direct from the Provincial Court to the Court of Appeal - such appeals lie from decisions on indictable offenses where the accused has elected trial by provincial court judge. It is not surprising that there is a considerable number of such appeals. Peter Russell has suggested that the practice of election on indictment means that Canadian provincial court judges "exercise a vast criminal jurisdiction which appears to be unmatched by the lower criminal courts of any other liberal democracy." 15 They constitute some $30 \%$ of conviction appeals in Alberta over the same period, but loom even larger in the sentence appeal caseload, comprising more than $70 \%$ of the total. Most of the time that an appeal court panel reconsiders a sentence, it is examining the decision of a provincial judge. presented here as anything other than a possible and partial explanation for the differences. 
Table 2: Sources and Success Rates of Sentence Appeals Alberta Court of Appeal, 1985-1992

\begin{tabular}{||l|l|l|l||}
\hline Source of Appeal & Number & $\begin{array}{l}\text { Percentage of } \\
\text { Total }\end{array}$ & Success Rate \\
\hline \hline Provincial Court & 2997 & $70.6 \%$ & $56.1 \%$ \\
\hline Queen' Bench & & & \\
second appeal' & 10 & $0.2 \%$ & $40.0 \%$ \\
judge \& jury & 5 & $0.2 \%$ & $60.0 \%$ \\
judge alone & 1233 & $29.1 \%$ & $40.3 \%$ \\
Total QB: & 1248 & $29.4 \%$ & $40.5 \%$ \\
\hline TOTAL: & $4245^{17}$ & & $51.4 \%$ \\
\hline
\end{tabular}

Not surprisingly, the relative prominence of Provincial Court appeals and Queen's Bench appeals varies according to the type of offence. In property-related offenses, appeals from provincial court are five times as numerous as appeals from Queen's Bench; in motor vehicle offenses, and in offenses regarding wrongful actions, they are three times as common. Appeals involving crimes against the person, however, are equally likely to come from provincial superior as from provincial inferior courts, and drug-related appeals from Queen's Bench are half again as frequent as those from provincial court. In general, these distinctions correlate with the seriousness of the offence (the average initial sentence on successful appeals from Queen's Bench is two years, from provincial court one year) but it is still important to stress the degree of overlap between the two sets of appeals.

Sentence appeals in Alberta are more than twice as frequent as conviction appeals (4255 sentence appeals compared with 1989 conviction appeals over the seven and a half years) as well as being roughly half again as likely to succeed $(51.4 \%$ for sentence appeals, compared with $35.0 \%$ for conviction appeals). ${ }^{18}$ This latter comment leads to the second observation: the relatively high success rate. As a general rule of thumb, appeal courts in Canada and the United States tend to uphold the trial decision about twice as often as they reverse it; ${ }^{19}$ Table 2 suggests that the Alberta Court of Appeal allows

Summary conviction offenses tried in Provincial Court and appealed to CQB before further appeal to the Court of Appeal.

17. Omits ten cases for which the name of the trial judge was not indicated.

18 For a comparable statistical consideration of conviction appeals, see P. McCormick, "Conviction Appeals to the Court of Appeal of Alberta: A Statistical Analysis 1985-1992" (1993) 31 Alta. L. Rev. 301 [hereinafter "Conviction Appeals"].

19 For figures on U.S. appellate experience, see C. Emmert, "An Integrated Case-Related Model of Judicial Decision-Making" 54 J. of Pol. (1992) 548; and Note "Courting Reversal: The Supervisory Role of State Supreme Courts: Explaining State Supreme Court Decisions in Judicial Review Cases" 
sentence appeals significantly more often than this - just over half the time. This is even more true of appeals that come direct from the provincial bench, which succeed $56 \%$ of the time, than it is for appeals from Queen's Bench, of which "only" $40 \%$ are successful.

Just as the ratio of the volume of appeals from the two trial benches varies according to the type of offence, so does the ratio of the success rate for appeals. Specifically, the general rule of thumb that an appeal from provincial court is 1.4 times as likely to succeed as an appeal from Court of Queen's Bench applies to property offenses, to crimes against the person, to drug offenses, and to crimes involving wrongful acts. This does not apply to motor vehicle offenses, where the court appealed from seems to have no effect on the prospect for reversal. The success rate for such appeals from provincial court is lower (at $48.6 \%$ ) than for any other type of offence; and the success rate for such appeals from Queen's bench is higher (at 47.9\%) than for any other type of offence. This convergence is particularly striking because it is not the case that a specific sub-category of motor vehicle offenses (like murder as a sub-category of crimes against the person) is statutorily reserved to provincial superior trial court.

In general, however, it should be stressed that both rates are rather high, and this in itself may go some distance to explaining the otherwise surprisingly high frequency of sentence appeals in Alberta. The high success rate is at first glance puzzling. By definition, a sentence appeal is one in which the trial judge's conviction of the accused has been upheld in a separate stage of the appeal process, or was not challenged at all. The Criminal Code and prior bench-mark decisions of the Court of Appeal bracket a range of possible sentences appropriate to the proven crime in question, and it is the responsibility of the trial judge to apply judgment, experience and discretion to identify an appropriate alternative within that bracket. Sometimes the trial judge may simply have erred; and sometimes the appeal panel may be declaring, not that the trial judge made a mistake, but that the Court of Appeal has changed its mind about the target at which trial judges should be aiming. However, one would expect that both such eventualities would be rather unusual, and that most appeals are simply asking another set of judges to look at a first judge's exercise of discretion defined by Aharon Barak as a situation in which an individual is faced by two or more alternatives, any one of which would be lawful. ${ }^{20}$ Justice Kerans has argued ${ }^{21}$ that, strictly speaking, an appeal should succeed only if the trial judge has wandered outside the legitimate range of discretion, not merely because one or more members of the appeal panel would have exercised that discretion differently, but the high success rates suggest that the Alberta Court of Appeal may not always resist the temptation to second-guess trial judges, as opposed to correcting them.

The third observation suggested by Table 2 is the extreme rarity of a sentence appeal from a jury trial, or of a "second appeal" of sentence on a summary conviction offence. The latter phenomenon seems to make sense on the face of it as summary conviction

(1978) 87 Yale LJ. For the experience of provincial courts of appeal, see C. Baar et al supra note 8. 
sentences are by definition shorter than indictable offence sentences, and a second appeal logically faces longer odds than a first appeal. The former, however, seems less selfevident; although a jury trial moves the determination of guilt from judge to jury, the sentencing decision is in either event a matter of the judge's discretion, and therefore the presence or absence of a jury would seem to have nothing to do with the motives and calculations that drive the decision to appeal, or that influence the likelihood of a successful sentence appeal. Both features may, however, be explained by a rather more prosaic consideration, that being that the relevant information may not have been as rigorously and scrupulously recorded as the more routinely critical items in the record (such as the nature of charge, the initial sentence, and the name of judge whose sentencing decision is being appealed).

\section{APPEALS OF WHAT? OFFENCE TYPES AND OUTCOMES}

Given the enormous diversity of the criminal trial caseload in Canada, a single omnibus success rate is not very useful. Table 3 refines this general information by dividing the caseload data among several major categories of offense (crimes against property, crimes against the person, motor vehicle offenses, etc.), and then further sub-dividing each category in terms of specific charges that occur most frequently in the appellate caseload.

Some sentence appeals involved multiple counts of the same offence, but they were still counted only once; other appeals involved multiple offenses, in which case the more serious category was used. The appellate caseload is, of course, hardly representative of the trial caseload. For one thing, the normal outcome of a guilty determination in a criminal trial in Canada is a fine rather than imprisonment, but almost all of the sentence appeal caseload dealt with outcomes involving incarceration.

Young offender appeals account for about one-seventh of all appeals, and are somewhat more likely to succeed than adult appeals (57.2\% compared to 51.0\%). Because Youth Court is part of the provincial bench, however, this overstates the difference, and the $57.2 \%$ success rate should be compared to the $56.1 \%$ reversal rate for that bench; in other words, there is no significant difference comparable to that observed for conviction appeals. Sentence appeals involving female defendants are much more unusual (less than one appeal in twenty), but they are more likely to succeed than appeals by male defendants (57.8\% against $51.1 \%$ ). The appeals of the 29 female young offenders succeeded $69.0 \%$ of the time, suggesting that the impact of this factor cuts across appeals from both benches, although the numbers are too small to permit confident generalization. 
Table 3: Elements of Caseload and Success Rates

Sentence Appeals, Alberta Court of Appeal 1985-1992

\begin{tabular}{||l||c|c|c||}
\hline \hline Type of Offense & appeals & as \% of caseload & success rate \\
\hline \hline crimes against property & & & \\
break \& enter & 1048 & $24.6 \%$ & $55.8 \%$ \\
theft & 469 & $11.0 \%$ & $58.0 \%$ \\
stolen property & 378 & $8.9 \%$ & $53.4 \%$ \\
fraud & 195 & $4.6 \%$ & $55.4 \%$ \\
mischief & 71 & $1.7 \%$ & $62.0 \%$ \\
other property & 28 & $0.7 \%$ & $35.7 \%$ \\
TOTAL PROPERTY: & 2189 & $51.5 \%$ & $55.8 \%$ \\
\hline crimes against the & & & \\
person: & & & \\
assault & 416 & $9.8 \%$ & $50.5 \%$ \\
sex offenses & 307 & $7.2 \%$ & $46.3 \%$ \\
robbery & 296 & $7.0 \%$ & $39.9 \%$ \\
murder/manslaughter & 85 & $2.0 \%$ & $34.1 \%$ \\
other person & 97 & $2.3 \%$ & $39.2 \%$ \\
TOTAL PERSON: & 1201 & $28.2 \%$ & $44.7 \%$ \\
\hline motor vehicle offenses: & & & \\
impaired driving & 84 & $2.0 \%$ & $47.6 \%$ \\
driving over .08 & 82 & $1.9 \%$ & $45.1 \%$ \\
dangerous operation & 62 & $1.5 \%$ & $46.8 \%$ \\
breath sample & 25 & $0.6 \%$ & $64.0 \%$ \\
other motor vehicle & 46 & $1.1 \%$ & $50.0 \%$ \\
TOTAL MOTOR & & & \\
VEHICLE: & 299 & $7.0 \%$ & $48.5 \%$ \\
\hline wrongful acts: & & & \\
weapon offenses & 95 & $2.2 \%$ & $59.0 \%$ \\
escape custody & 81 & $1.9 \%$ & $48.5 \%$ \\
other wrongful & 101 & $2.4 \%$ & $57.0 \%$ \\
TOTAL WRONGFUL: & 277 & $6.5 \%$ & $45.6 \%$ \\
\hline drug related offenses & 263 & $6.2 \%$ & $26.9 \%$ \\
\hline other/misc./not given & 26 & $0.6 \%$ & $51.4 \%$ \\
\hline TOTAL: & 4255 & & \\
\hline & & & \\
\hline
\end{tabular}


Crimes against the person and crimes against property dominate the sentence appeal caseload just as they dominate the conviction appeal caseload, ${ }^{22}$ although their relative proportions are reversed: in conviction appeals, crimes against the person are more numerous $(34.4 \%)$ than crimes against property $(24.4 \%)$, but in sentence appeals crimes against property $(51.5 \%)$ are much more frequent than crimes against the person $(28.2 \%)$. Almost $20 \%$ of conviction appeals involve motor vehicle offenses, but this category accounts for only about one-third as many sentence appeals; drug-related offenses and wrongful acts make up similarly small proportions of both sentence and conviction appeals.

Appeals involving crimes against the person are the least likely to be allowed, especially murder/manslaughter cases which succeed barely one-third of the time; drugrelated offenses (the large majority of which are "trafficking" or "possession for purposes of trafficking" charges) face comparable prospects. Motor vehicle offenses generally succeed less often than average, with the striking exception of "breathalyser" and "breath sample" charges which are allowed most of the time; this is an intriguing exception whose significance is clouded by the rather small number of cases involved - barely three a year.

At the other extreme, appeals involving wrongful acts are the most likely to succeed, especially "escape lawful custody" charges which are allowed almost two-thirds of the time. Sentence appeals for property-related offenses also succeed more often than average, especially theft and mischief charges.

In general terms, it would normally seem plausible to suggest that reversal rates reflect the nature of the trial/appeal interface: low reversal rates indicate that the sentencing patterns of trial judges and appeal judges are generally "in sync," while high reversal rates indicate either that the appeal court is trying to change the normal tariff or that trial judge novelty is being resisted. However, the overall reversal rate is so high, and the intercategory variations so modest, that it seems difficult to apply such an analysis to these results; the background noise is so high that the message is obscured.

\section{APPEALS FROM WHOM? THE ALBERTA TRIAL BENCHES}

To state the obvious: every sentence appeal can be tracked back to a single specific trial judge ${ }^{23}$ and every one of those appeals was either allowed or dismissed. This information can be turned into tabular form, recording how often each trial judge was appealed and how frequently those appeals succeeded. This information is summarized in Table 4.

23. Omitting 12 cases for which the name of the trial judge was not recorded. 
Table 4: Number of Appeals and Frequency of Reversal, By Bench

Sentence Appeals to the Alberta Court of Appeal, 1985-1992

\begin{tabular}{||l|ll|l|ll||}
\hline $\begin{array}{l}\text { Number of } \\
\text { Appeals }\end{array}$ & \multicolumn{2}{|c|}{$\begin{array}{l}\text { Number of judges } \\
\text { QB ProvCt }\end{array}$} & $\begin{array}{l}\text { Reversal } \\
\text { Frequency }\end{array}$ & \multicolumn{2}{|c|}{$\begin{array}{l}\text { Number of judges } \\
\text { QB ProvCt }\end{array}$} \\
\hline \hline $75+$ & - & 2 & $70 \%+$ & 1 & 9 \\
\hline $50-74$ & - & 10 & $60-69 \%$ & 6 & 27 \\
\hline $40-49$ & 1 & 6 & $50-59 \%$ & 14 & 45 \\
\hline $30-39$ & 6 & 17 & $40-49 \%$ & 11 & 20 \\
\hline $20-29$ & 19 & 29 & $30-39 \%$ & 22 & 10 \\
\hline $10-19$ & 28 & 39 & $20-29 \%$ & 9 & 6 \\
\hline $0-9$ & 21 & 36 & $10-19 \%$ & 4 & - \\
\hline
\end{tabular}

The logical assumption would be that there is some degree of correlation between the two sides of the table: that is, that there are some judges who are appealed unusually often and some judges who are reversed unusually frequently, and that these are in fact the same judges. If the major function of appeal is the correction of error, ${ }^{25}$ then a judge's reversal rate suggests the frequency of error, and the frequency of appeal indicates the legitimate response of counsel to the errors that need correction. This in turn suggests that Table 4 could be turned into a merit evaluation tool, extremely crude for any single case, but more credible as the numbers accumulate, with the poorer judge rising to the top of the table and the better judges settling toward the bottom.

But this "obvious" logic breaks down at the very beginning, because there is in fact no correlation whatever between the frequency of appeal and the frequency of success. There is a single provincial Court Judge whose sentences have been appealed 115 times, almost six times the average number for that bench, but that judge is not reversed more often, or even as often, as other provincial judges, posting a reversal rate that is comparable, not just to the average for this bench, but to the average for the provincial superior bench. These comments can be generalized: the twelve most frequently appealed provincial judges, and the twelve most frequently reversed provincial judges, are twenty-three different individuals. Similarly, the twelve most frequently appealed Queen's Bench judges, and the twelve Queen's Bench judges most often reversed, are twenty-four different individuals. The submerged assumption that many laypeople probably carry about the appeal process - that it is a way of minimizing the damage wreaked by a handful of sub-par trial judges - is completely and demonstrably wide of the mark.

24. Omits all judges with fewer than five appeals.

25 Not, to be sure, a comment that can be casually generalized, but one that seems plausible for sentence appeals. 
Indeed, if there is any correlation between the two sets of figures, it is the reverse of what one might have expected. It seems to be the case, at least for Queen's Bench judges, that the most frequently appealed judges are reversed least often, and the least frequently appealed judges are reversed most often. The one-third of Queen's Bench judges appealed most often are reversed $38.6 \%$ of the time; the middle third $42.7 \%$; and the least frequently appealed third $44.5 \%$ The argument should not be pushed too far - what does it prove if a judge is appealed only three times and reversed twice? - - but its general outlines are intriguing. It would seem to be the case that we should look for an explanation of the phenomenon of appeal not in terms of the specific judge, in the sense of a sub-set of individuals who err much more often than usual, but in terms of the specific accused in the specific case or in terms of the general trial/appeal interface (that is, frequency of success is high enough that it encourages defendants to "take a chance").

\section{APPEALS BY WHOM: CROWN APPEALS AND DEFENDANT APPEALS}

The most critical distinction in sentence appeals is between those initiated by the defendant and those initiated by the Crown. It is a common thesis of the "law and society" literature that the judicial system, at both the trial and appellate level, tends to favour "repeat performers" (such as Crown prosecutors) over "one-shotters" (such as criminal defendants), not because of any bias on the part of judges but because of structural advantages that accrue to the regular players. ${ }^{26}$

More specifically, the Crown can both organize its appeals on the basis of a coherent and long-term strategy, and decide on a broad and rational basis where to locate the cutoff point of cost versus probable outcome. The advantages of bureaucratic organization also suggest that it can do so on the basis of more complete and systematized information as well, while a hierarchy of proven ability within the Crown prosecutor's office puts the strongest performers into appeal court, especially for the cases deemed to be the most important. Crown appeals reflect a bureaucratic decision anticipating a line of decisions that will differ from that of the trial bench (and will therefore ripple out to influence the pattern of future trials) and a willingness to invest the legal resources to bring about that change. For defendants, the decision to appeal grows from a combination of advice by counsel, financial means, and the negative impact of a specific sentence: if the impact is sufficiently devastating, then even a remote chance of success logically justifies an appeal. However, it seldom makes sense for a criminal defendant to seek an appeal for the purposes of altering the future flow of trial judge actions, nor do they usually have the resources to invest in such a purpose.

See for example, M. Galanter's discussion of trial courts in "Why the 'Haves' Come out Ahead: Speculations on the Limits of Legal Change" (1974) 95 Law and Society Review; the same model is applied to appellate courts by S. Wheeler, B. Cartwright, R. Kagan \& L. Friedman, "Do the 'Haves' Come Out Ahead? Winning and Losing in State Supreme Courts 1870-1970" (1987) 21 Law and Society Review, and D.R. Songer \& R.S. Sheehan "Who Wins on Appeal? Upperdogs and Underdogs in the United States Courts of Appeals" (1992) 36 American Journal of Political Science. 
In general, Crown appeals of sentence are slightly more successful than defendant appeals, although the net advantage (Crown success rate as appellant, less Crown loss rate as respondent in defendant appeals) is very small -- barely 3\%, compared with a much more robust $24 \%$ on conviction appeals. ${ }^{27}$ However, there are such great variations from one type of offence to another in the ratio of Crown appeals to defendant appeals, and in the relative success rates of the two types of appeal, that the general statement is uninformative, even misleading. A breakdown by type of offense is provided in Table 5 .

Table 5: Frequency and Success Rate of Crown Appeals by

Type of Offence; Alberta Sentence Appeals, 1985-1992

\begin{tabular}{||l|l|l|l||}
\hline & $\begin{array}{l}\text { Crown appeals as } \\
\% \text { of all appeals }\end{array}$ & $\begin{array}{l}\text { Crown appeal } \\
\text { success rate }\end{array}$ & $\begin{array}{l}\text { Defendant appeal } \\
\text { success rate }\end{array}$ \\
\hline $\begin{array}{l}\text { crimes against } \\
\text { property }\end{array}$ & $7.7 \%$ & $52.4 \%$ & $56.1 \%$ \\
\hline $\begin{array}{l}\text { crimes against } \\
\text { the person }\end{array}$ & $26.7 \%$ & $55.8 \%$ & $40.7 \%$ \\
\hline $\begin{array}{l}\text { motor vehicle } \\
\text { offenses }\end{array}$ & $14.1 \%$ & $54.8 \%$ & $47.5 \%$ \\
\hline $\begin{array}{l}\text { wrongful acts } \\
\text { drug-related } \\
\text { offenses }\end{array}$ & $10.9 \%$ & $43.3 \%$ & $58.9 \%$ \\
\hline \begin{tabular}{l} 
All appeals: \\
\hline
\end{tabular} & $14.6 \%$ & $55.0 \%$ & $42.9 \%$ \\
\hline
\end{tabular}

Overall, the Crown initiates about one-seventh of all sentence appeals, succeeding in $54.0 \%$ of the appeals that it brings and losing $51.0 \%$ of the cases where it appears as respondent. However, the only category closely reflecting this tendency is motor vehicle offenses, where the pattern of all three ratios is very close to the overall figures. For appeals involving crimes against property and crimes involving wrongful acts, however, Crown appeals are both very infrequent (one-twelfth and one-ninth of the total) and tend to succeed less often than defendant appeals. This is contrary to the expectations of Galanter's party capability thesis, the "repeat performer" Crown enjoys a net disadvantage (of $-3.7 \%$ for property offenses, $-15.6 \%$ for wrongful acts) relative to "one-shotter" defendants. The Crown/defendant balance carved out in the trial courts is altered by the appeal panels in favour of defendants.

The pattern is completely different for crimes against the person and for drug-related offenses. Here, the Crown initiates far more appeals (roughly one-quarter of the total) and 
it succeeds more often than average as both appellant and respondent. It enjoys a significant net advantage of $+12.1 \%$ on drug-related offenses and $+15.8 \%$ on crimes against the person. The Crown/defendant balance that emerged from the trial courts is altered significantly in favour of the Crown. To make the contrast explicit: on conviction appeals, the Crown enjoys a significant net advantage for all types of offenses except crimes against property, although its initiation rate and success rate are both below average for crimes against the person.

\section{APPEALS TO WHOM? PANEL COMPOSITION AND OUTCOMES}

The most outstanding feature of sentence appeals in the Alberta Court of Appeal is the extensive use of provincial superior trial court judges sitting as ad hoc judges of the Court of Appeal. In some provinces (such as B.C. and Ontario ${ }^{28}$ ) this never happens; in others (such as Saskatchewan and Manitoba ${ }^{29}$ ) it happens only rarely, when illness or refusal or other assignments makes it otherwise difficult to form a panel. In Quebec, a single provincial superior court judge served for several years as a more or less permanent ad hoc (or adjoint) judge of the Court of Appeal, but more recently the Court expanded its number of full time members rather than extending the ad hoc practice. Only Alberta uses trial judges to fill out appeal panels on a regular basis, and the practice is particularly pronounced on sentence appeals. ${ }^{30}$

Information on panel composition is available for about three-quarters (77.1\%) of the 4255 sentence appeals decided in Alberta between January 1, 1985 and June 30, 1992. ${ }^{31}$ Only $11 \%$ of these were decided by panels comprised exclusively of three Court of Appeal justices; another $9.4 \%$ were decided by panels including a single ad hoc judge; but an overwhelming $79.3 \%$ were resolved by panels including two ad hoc judges and a single Court of Appeal justice. The use of trial judges on appeal panels is not just a regular practice in Alberta; it is the normal practice. Of the five judges who participated in more than 500 sentence appeal decisions, four are Court of Queen's Bench judges, and superior court trial judges combine for more panel appearances than appeal court judges.

The relevant legislation in Ontario does permit the use of trial judges as ad hoc appeal judges, but I am informed that a series of provincial Chief Justices have been so firmly opposed to the practice that the legislative permission is virtually a dead letter.

In Manitoba, for example, the use of a trial judge to sit ad hoc happens only about half a dozen times a year, sometimes less. For statistics, see Caseload and Output, supra note 9.

I understand that the use of single ad hoc judges on conviction and civil appeal panels is intended primarily to introduce junior $C Q B$ judges to the way that the appeal function operates, and the designation of specific individuals is made by the Chief Justice of CQB. The two ad hoc judges serving on sentence appeals, on the other hand, are intended to be experienced senior judges of the $\mathrm{CQB}$, and the designation of specific individuals in made jointly by the two Chief Justices.

Most of the shortfall is caused by the fact that the information was not recorded by the Edmonton Registrar's office before June 1987; information on panel composition for Edmonton since that date and for Calgary for the whole period, is all-but complete, which renders the lack less debilitating for analytical purposes than would more scattered and pervasive omissions. 
The obvious question is whether this makes a difference. At first glance, it would seem that it does: panels comprised exclusively of appeal court judges allow $54.7 \%$ of the appeals they hear; panels including one or more ad hoc judges allow the appeal only $49.6 \%$ of the time. However, this would be conclusive only if the assignment of cases to panels were purely random, and it seems obvious on the face of it that it would not be. If the "normal" practice is to use ad hoc judges, then there would have to be something unusual about an appeal (urgency, or a perceived need for a benchmark decision to direct future sentencing practices, or whatever) for it to be one of the $10 \%$ of all such cases referred to an all-appeal judge panel.

To approach the same question from a different angle: the panel participation of each judge can be reduced to a series of "votes" on whether or not to reverse the trial judge ${ }^{32}$ (and, by the same logic, whether or not to support the Crown by allowing Crown appeals or dismissing defendant appeals ${ }^{33}$ ). To refine the logic a little more precisely, we can identify three different categories of judges: Queen's Bench judges sitting ad hoc; appeal court judges with trial bench service before their elevation to the appeal bench; and appeal court judges with no judicial experience prior to their appellate appointment. The logic of this division is to identify the extremes of those judges who have never served full-time on the appeal bench, and those who have never served full-time on another bench, with elevated judges falling in between. The results are shown in Table 6.

Table 6: Frequency of Votes to Reverse and pro-Crown Votes, by Type of Judge; Sentence Appeals to Alberta Court of Appeal

\begin{tabular}{||l|l|l|l||}
\hline & $\begin{array}{l}\text { panel } \\
\text { appearances }\end{array}$ & $\begin{array}{l}\text { votes to } \\
\text { reverse }\end{array}$ & $\begin{array}{l}\text { pro-Crown } \\
\text { votes }\end{array}$ \\
\hline \hline CQB judges sitting ad hoc & 5511 & $49.7 \%$ & $51.9 \%$ \\
\hline $\begin{array}{l}\text { appeal judges with trial } \\
\text { experience }\end{array}$ & 2596 & $49.4 \%$ & $50.7 \%$ \\
\hline $\begin{array}{l}\text { appeal judges w/o trial } \\
\text { experience }\end{array}$ & 1736 & $54.0 \%$ & $49.1 \%$ \\
\hline All judges: & 9843 & $50.4 \%$ & $51.5 \%$ \\
\hline
\end{tabular}

The differences are not large, nor would they become dramatically larger if Table 6 were expanded to show every individual judge's votes rather than composite categories. No appeal court judge, and only one Queen's Bench judge, voted to reverse less than 45\% of the time or more than $60 \%$ of the time; no Queen's Bench judge, and only two appeal court judges, voted with the Crown more than $60 \%$ of the time, or less than $40 \%$ of the 
time. However, even these small differences can have a significant impact over the high volume of sentence appeals processed by the Alberta Court of Appeal, and in general it would seem to be the case that appeal judges without trial experience are more likely to allow the appeal, and less likely to support the Crown, than are judges who are at that time serving, or who have served in the past, as members of the trial bench. ${ }^{34}$ To a small but significant extent, judges with trial experience are more likely to respect the discretion and the judgment of the trial judge, while judges without trial experience are more likely to replace it with their own.

\section{APPEAL FOR WHAT? DO APPEAL JUDGES TINKER?}

It is a common complaint of Alberta trial judges ${ }^{35}$ that the Court of Appeal is inclined to "tinker" with sentence appeals - that is, to allow sentence appeals in order to make minor adjustments to the sentence, rather than to correct significant error or to provide future guidance, while at the same time acknowledging trial judge discretion on details. This question is easily answered in terms of the data base assembled for this project. On those successful appeals that a change in sentence was the recorded result ${ }^{36}$ the percentage reduction in sentence for defendant appeals and the percentage increase in Crown appeals can be calculated and compared.

Overall, the median ${ }^{37}$ reduction in sentence for a successful defendant appeal is $50 \%$, and the median reduction for each category of offense is comparable (from $49.9 \%$ for crimes against the person, to a high of $58.9 \%$ for wrongful acts). The median increase in sentence for a successful Crown appeal is $100.5 \%$, and it is at least this high for every category of offense (with the highest, at $170.7 \%$, for property offenses).

This is not to deny that individual characteristics remain more important than the broad-brush portrait suggested above. Specifically: there are four judges who best characterize the high reversal/low proCrown votes of one wing of the court, and four others who best characterize the low reversal/high pro-Crown vote of another wing; judges elevated from the trial bench constitute a majority of both sets.

Comment based on personal interviews with 41 Alberta trial judges in 1984 and 1985; the findings are discussed at some length in P. McCormick \& I. Greene, Judges and Judging: Inside the Canadian Judicial System (Toronto: James Lorimer \& Company, 1990).

This implies a double reduction in the number of cases used in the calculations: first, there were a number of cases for which either or both of the initial sentence and the new sentence were not recorded; and a much larger number for which the altered outcome did not result in an altered period of incarceration but rather a change to other features of the sentence - eligibility for parole, length of probation or of a license suspension or a weapons ban, changes from closed to open custody for young offenders, etc. There were also a small number of sentence appeals that resulted in a new trial by allowing a guilty plea to be withdrawn.

This discussion will be based upon median changes in sentence - - that number for which there are an equal number of cases larger and smaller - rather than upon the average change because some sentence increases (e.g. from one day to three months) are so large as to render average figures misleading. 
Table 7: Frequency of Ranges of Sentence Reduction/Increase

Sentence Appeals to the Alberta Court of Appeal, 1985-1992

\begin{tabular}{||l|l|l|l||}
\hline $\begin{array}{l}\text { Range of sentence } \\
\text { reduction }\end{array}$ & $\begin{array}{l}\text { Number } \\
\text { of cases }\end{array}$ & $\begin{array}{l}\text { Range of sentence } \\
\text { increase }\end{array}$ & $\begin{array}{l}\text { Number } \\
\text { of cases }\end{array}$ \\
\hline \hline $0-9 \%$ & 21 & $0-49 \%$ & 24 \\
\hline $10-24 \%$ & 109 & $50-99 \%$ & 56 \\
\hline $25-49 \%$ & 469 & $100-199 \%$ & 60 \\
\hline $50-74 \%$ & 660 & $200-499 \%$ & 32 \\
\hline $75 \%+$ & 275 & $500 \%+$ & 37 \\
\hline
\end{tabular}

Table 7 shows how many successful appeals fall within specific proportions of sentence increase or decrease, thereby demonstrating the extent to which successful defendant and Crown appeals both cluster closely around the median figure. Only a small number of successful appeals - arguably, the top line for both reduction and increase - generate an outcome that can plausibly be described as "tinkering," and these amount to only 45 of the 1743 cases of which numbers were relevant and available. Even this overstates the case; three of the 21 minor reductions involved sentences of "time in custody" and another 14 involved changes between sentences of "two years" and of "two years less a day." ${ }^{138}$ That is, the former were the largest reductions possible under the circumstances, and the latter were cases where the major point of contention is less the length of sentence than whether the incarceration is in a federal penitentiary or a provincial jail. Conversely, the small percentage increases were for sentences that were already several years long; the smallest absolute increase in sentence was five months.

The figures are conclusive in demonstrating that the Court of Appeal does not tinker, that the overwhelming proportion of its increases and reductions of sentence are very substantial indeed - so much so that it seems curious that so many trial judges would report the opposite impression. Most plausibly, the explanation has to do with the anecdotal nature of the "evidence" suggested by those judges; of those reports of the outcome of sentence appeals received by any judge, the ones that would stand out in memory as the most striking would be the small number involving a minor alteration of sentence rather than the larger number resulting in large changes. By the same token, these striking examples would fuel the coffee room grumbling that would reinforce an awareness of the phenomenon, making it appear much more pronounced than statistical exploration would support. to "two years," an outcome which struck me as anomalous although several appeal judges have said such an appeal is not that infrequent. 
But the fact that the frequent reversals of sentence appeals do not appear to be tinkering just pushes the question one step further: what is it that explains the high rate of reversal? The absence of a correlation between the frequency of appeal for specific trial judges and the frequency of reversal seems to suggest that there is no unusual degree of error on the part of trial judges calling for correction, as does the fact that conviction appeals in Alberta succeed no more often than conviction appeals in other provinces. The limited precedential value of any single sentence appeal (leaving aside the infrequent exception of benchmark decisions) speaks against a law-making function. It is possible that an answer might be found in the third of the standard appeal court functions, legal uniformity, if we assume either that the intraprovincial diversity in sentencing creates a significant problem, or that the Alberta Court of Appeal is unusually vigilant in trying to promote a uniformity in sentencing. Confirming either of these hypotheses is beyond the scope of the present paper.

A final possibility, already hinted at above, is that appeal panels may be creating an additional function, a "discretion substitution" function, that dominates the outcome of sentence appeals. It has been suggested to me by a member of the Court that this readiness to intervene is to some extent a product of the high volume of sentence appeals. Because the Court of Appeal is called upon to reconsider so many sentences, it develops a familiarity with the range of crimes and sentences and therefore a firm sense of exactly what appropriate sentencing practices should look like. An appeal court with a smaller number of sentence appeals has less occasion to develop this familiarity, and is therefore more likely to acquiesce in the judgment of the trial judge, a tendency that is reinforced by the fact that a significant number of appeal court judges do not have criminal trial experience (as lawyer or as judge) before appointment to the appeal bench.

\section{CONCLUSION}

The basic context of sentence appeals is the same in all ten provinces. There is a single national Criminal Code which provides the bulk of the appellate criminal caseload, and this Code is subject to the authoritative interpretation of a single national court of appeal, the Supreme Court of Canada; the fact that the Supreme Court has, in the last decade, vastly increased the size of the criminal component of its caseload ${ }^{39}$ suggests that it is providing more leadership in this area of the law than has been the case in the past. The structure of the provincial court systems is increasingly similar as the merger movement carries more and more provinces to a single provincial superior trial court; and the judges of the appeal courts and the higher trial courts are appointed by the same national government. This is unlike the American system which seems to build in a degree of conflict, or at least of difference, between state and federal courts.

All of these factors create the expectation of a roughly similar pattern in the caseload and output of the various provincial courts of appeal, an expectation which is clearly not fulfilled. The Alberta Court of Appeal in particular has developed its own unique aspects 
to the handling of sentence appeals - an enormous volume of appeals, routinely handled by trial judges sitting ad hoc to an extent that has no counterpart in other provinces, and with a surprisingly high reversal rate accompanied by large rather than small adjustments to the initial sentence.

A member of the Court who commented on an earlier draft of this article mentioned "four great myths" that were widely assumed (certainly by the Court itself, and presumably by the legal profession of which it is a part) to be true. The first was the myth that appeal judges tinker with sentences; the second ${ }^{40}$ was the myth that the Court is much more ready to reverse provincial judges than provincial superior court judges; the third was the myth that the ad hoc judges have limited impact because of their tendency to defer to the appeal judges, especially when there is only a single ad hoc judge on the panel; and the fourth is the myth that much of the workload of the appeal court consists of keeping a handful of weaker trial judges in line. None of these four myths can be sustained by the empirical data discussed in this article.

The very uniqueness of Alberta qualifies the extent to which these findings can be generalized to other provinces, and the "changing of the guard" as the Fraser Court replaces the Laycraft Court may portend new styles of leadership and action. That said, the database on sentence appeals during the period of the Laycraft Chief Justiceship provides an unusual window on one of the high-volume components of the appellate caseload, and a useful background to the individual appeal decisions that are the normal material of legal research and analysis. 